\title{
Allelopathic momilactones $A$ and $B$ are implied in rice drought and salinity tolerance, not weed resistance
}

\author{
Tran Dang Xuan ${ }^{1}$ - Truong Ngoc Minh ${ }^{1}$ • La Hoang Anh ${ }^{1}$ • Tran Dang Khanh ${ }^{2}$
}

Accepted: 24 June 2016 / Published online: 9 September 2016

(C) INRA and Springer-Verlag France 2016

\begin{abstract}
Momilactones A and B are allopathic phytoalexins that are involved in weed resistance of rice. There is little knowledge on the roles of momilactones $\mathrm{A}$ and $\mathrm{B}$ on drought and salinity tolerance. Here we analyzed the contents of momilactones $\mathrm{A}$ and $\mathrm{B}$ in 30 rice cultivars of various origins including hybrid, foreign, sticky, local, upland sticky, and upland rice of the two subtypes Indica and Japonica. Momilactone contents were compared with salinity tolerance, drought tolerance, weed resistance, total flavonoids, total phenols, and antioxidant capacity. Results show that, contrary to the current knowledge, momilactones $\mathrm{A}$ and $\mathrm{B}$ have very low correlation with weed resistance, with $\mathrm{r}$ coefficients of 0.001 and 0.09 , respectively. Correlation was higher with drought tolerance, of 0.65 for momilactones $\mathrm{A}$ and 0.27 for momilactones B. Overall we conclude that the development of bioactive reagents derived from momilactones $\mathrm{A}$ and B is more potent to reduce salinity and drought stresses than weed tolerance in rice.
\end{abstract}

Keywords Correlation coefficient · Drought tolerance · Momilactone A · Momilactone B · Salinity tolerance $\cdot$ Weed resistance

Tran Dang Xuan

tdxuan@hiroshima-u.ac.jp

1 Graduate School for International Development and Cooperation, Hiroshima University, 1-5-1 Kagamiyama, Higashihiroshima 739-8529, Japan

2 Agricultural Genetics Institute, Pham Van Dong street, Hanoi, Vietnam

\section{Introduction}

Rice is a staple food crop for more than $50 \%$ of the world population and about $90 \%$ of the world's rice is produced in Asia (Nachimuth et al. 2015). World rice production has to increase by at least $70 \%$ by 2050 in order to meet the demand of the population. However, rice production has been seriously threatened by abiotic stresses such as drought, salinity, subemergence, weeds, and pest and disease infestation. Of them, salinity and drought are among major problems to reduce rice yield and quality. Drought stress is the most important constraint to rice production, affecting 10 million ha of upland rice and over 13 million ha of rainfed lowland rice in Asia alone (Pandey et al. 2007). The increasing threat of salinity has become an essential concern linked to the consequences of climate change. Sea-level rise will increase salinity encroachment in coastal and delta areas that have previously been favorable for rice production.

Momilactones A and B were first isolated from rice husks as plant growth inhibitors (Kato et al. 1973), and reported as phytoalexins (Fig. 1) against the fungal rice blast disease pathogen Magnaporthe oryzae in rice leaves and straw (Cartwright et al. 1977, 1981). The function of momilactone A as a phytoalenxin was extensively studied against fungal pathogens (Fukuta et al. 2007; Okada et al. 2007; Hasegawa et al. 2010), whereas momilactone B was much less described (Fukuta et al. 2007). Among potential growth inhibitors detected in rice including phenolic acids, fatty acids, phenylalkanoic acids, hydroxyamic acids, terpenes, and indoles, momilactones A and B particularly play a critical role (Kato-Noguchi and Peters 2013). Extensive trials in fields (Chung et al. 2006) and laboratories have been conducted to verify the roles of momilactones A and B toward weed resistance (Kato-Noguchi et al. 2008a, b; Chung et al. 2006, Fukuta et al. 2007; Toyomasu et al. 2008). 


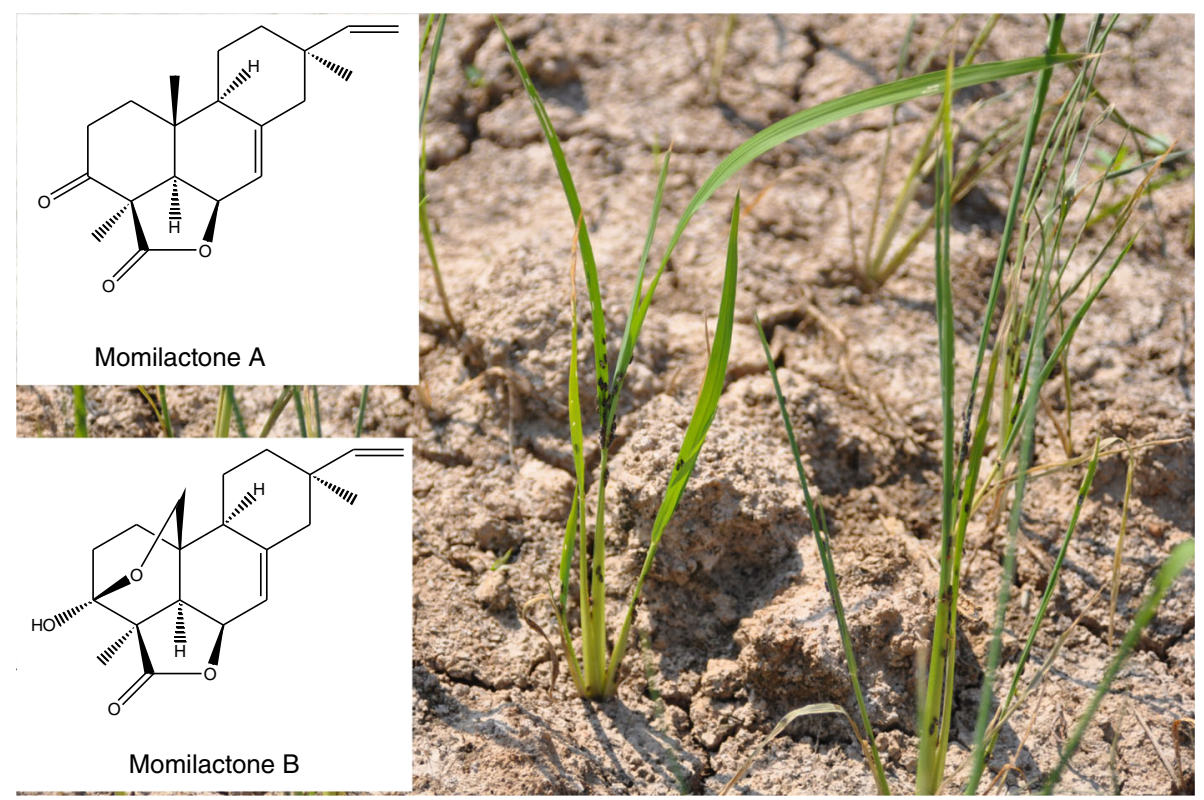

Fig. 1 Chemical structures of momilactones A and B derived from rice plants

Contents of momilactones A and $\mathrm{B}$ in rice plants have been known to be varietal dependent (Chung et al. 2006; Kato-Noguchi and Ino 2005). However, the identification and quantification of momilactones $\mathrm{A}$ and $\mathrm{B}$ were often conducted in rice with strong weed suppressing ability such as PI312777 (Kong et al. 2006; Kong et al. 2004). Only a few commercial rice have been analyzed, such as momilactone B in eight common Japanese cultivars was quantified (Kato-Noguchi and Ino 2005), however, the morphological and agronomic characteristics correlated to momilactone $\mathrm{B}$ were not described. Chung et al. (2006) quantified momilactones A and B in 99 rice, and found that rice varieties with awns, and later maturing times contained higher levels of momilactones A and B, but most of the studied cultivars were not commercial rice. Therefore, the actual weed resistant strength of momilactones A and B in commercial rice should be elaborated. In addition, influences of momilactones A and B to drought and salinity tolerance of rice have never been demonstrated.

In this study, contents of momilactones $\mathrm{A}$ and $\mathrm{B}$ in different origins and subtypes of commercial rice including hybrid, foreign [from IRRI (International Rice Research Institute)], local, sticky, upland, and upland sticky, and subtypes Indica and Japonica were quantified. The abiotic stresses including drought and salinity tolerance and weed resistance in correlation with chemical components consisting of momilactones $\mathrm{A}$ and $\mathrm{B}$, total phenols, and flavonoids were analyzed. The present research also examined whether momilactones A and B can be used as bioactive reagents to reduce abiotic stresses in rice production.

\section{Materials and methods}

\subsection{Chemicals}

The analytical grade chemicals including acetone, ethyl acetate, Folin-Ciocalteu's reagent, aluminum chloride, 1,1diphenyl-2-picrylhydrazyl (DPPH), and sodium carbonate, were purchased from KANTO Chemical, Tokyo, Japan.

\subsection{Isolation of momilactones A and B}

Momilactones A and B from rice husks were isolated according to the method described by Chung et al. (2006) with some modifications. Amounts of $150 \mathrm{mg}$ for momilactone A and $100 \mathrm{mg}$ momilactone B were obtained from $10 \mathrm{~kg}$ rice husks. The structures of momilactones $\mathrm{A}$ and $\mathrm{B}$ were confirmed by a $500 \mathrm{MHz}$ nuclear magnetic resonance (NMR) using a JEOL JNM-ECA400 applied with $1 \mathrm{D}$ and $2 \mathrm{D}$ spectral methods, aided by electron ionization mass spectrometry (EI-MS) using a Hitachi M-2500, and compared with those in literature.

\subsection{Rice cultivars}

Thirty rice cultivars from different origins including (i) hybrid rice (cultivar names: AI1, AI5, AII3, AIII4, and AIV4; subtype: Indica; country: China), (ii) foreign (cultivar names: BI5, BII1, BII3, BII4, and BIII3; subtype: Indica; country: the Philippines, IRRI), (iii) sticky (cultivar names; BIII4, BIII5, BI1, BIV3, and BV1; subtype: Japonica; country: Vietnam), (iv) local (cultivar names: CI1, CI2, CI3, CII5, CII4, and CII5; subtype: Indica; country: Vietnam), (v) upland sticky (cultivar 
names: CII3, CII4, CIV1, CIV2, and CIV3; subtype: Japonica; country; Vietnam), and (vi) upland (cultivar names: BV2, BV4, BV5, CV3, and BV3; subtype: Japonica; country: Vietnam). The germination rate of rice seeds was checked in random and $>95 \%$.

\subsection{Salinity tolerance}

Seeds were surface-sterilized by soaking in $0.1 \% \mathrm{NaOCl}$ for $30 \mathrm{~min}$, washed in distilled water, and then germinated in Petri dishes for 5 days. The germinated seeds were placed in screening trays (ten holes in a row with one healthy seeding in each hole for one test entry), filled with nutrient water for one week. The genotypes were screened for salt tolerance at seedling stage in hydroponic scheme using IRRI standard protocol (Gregorio et al. 1997). Salinized and nonsalinized setups with three replications were maintained. The evaluation was carried out using Yoshida et al. (1976) nutrient solution at the greenhouse. The nutrient solution was changed every 8 days. $\mathrm{NaCl}$ was added into these trays to obtain desired EC at $5 \mathrm{dS}$ $\mathrm{m}^{-1}$ and $10 \mathrm{dS} \mathrm{m}{ }^{-1}$. Trays without salt considered as the control $\left(0 \mathrm{dS} \mathrm{m}{ }^{-1}\right)$. The EC of the water were checked using an EC meter (Hanna HI 4321, USA). The survival plants were selected randomly in all treatments to record shoot height, root length, and fresh and dry weight after 30 days after treatment. Salinity tolerance as the inhibition (\% of controls) of each concentrations on shoot height, root length, and fresh and dry weight were calculated.

\subsection{Drought tolerance}

Similar rice seeds as mentioned above were used. The sterilized seeds were soaked in distilled water, and germinated in plastic trays in an incubator. After 15 days, they were transplanted into plastic pots $(20 \mathrm{~cm}$ in diameter, $15 \mathrm{~cm}$ height) filled with sterilized soil. The pots were placed in a greenhouse affiliated to the University of the Ryukyus, Okinawa, Japan, in July-August 2010-2011 (temperature was $30{ }^{\circ} \mathrm{C}$ in average). Two weeks of after transplanting, water was not provided until measurements were conducted. Controls received water daily. Drought tolerance as the inhibition (\% of controls) of each concentrations on shoot height, root length, and fresh and dry weight were calculated.

\subsection{Weed resistance}

The mentioned above rice seedlings were transplanted in $2 \times 3 \mathrm{~m}$ concreted blocks in a greenhouse affiliated to the University of the Ryukyus, Okinawa, Japan in JulyAugust, 2010-2011. At 1 month after transplanting, paddy weed biomass at $20 \times 20 \mathrm{~cm}$ areas were taken, cleaned by tap water, and dried at $35{ }^{\circ} \mathrm{C}$ for a week. Controls were the blocks that received no rice transplanting. Weed resistance as the inhibition (\% of controls) of each treatments on weed biomass were determined.

\subsection{Quantification of momilactones A and B}

Content of momilactones $\mathrm{A}$ and $\mathrm{B}$ in rice plants were quantified using a gas chromatography-mass spectrometry (GC-MS). Upland parts of rice plants were harvested from a greenhouse, kept in sealed plastic bags, and transferred immediately to laboratory. The rice plants were dried in an oven in the dark at $35{ }^{\circ} \mathrm{C}$ for a week and ground into powder. An amount of $5 \mathrm{~g}$ plant power was immersed in methanol $(\mathrm{MeOH})$ and shaken $(80$ $\mathrm{rmp}$ ) for 2 days at room temperature and filtered through Whatman No.1 filter paper. After removal of methanol by a rotary evaporator, the residues was suspended in water and extracted successively with ethyl acetate (EtOAc), and filtered. The supernatant was evaporated until dryness and dilluted in acetone to yield a 1000 ppm solvent. It was filtered through a $20 \mu \mathrm{l}$ filter and injected into GC-MS for quantification of momilactones $\mathrm{A}$ and $\mathrm{B}$.

Momilactones A and B were identified and quantified by GC-MS (QP-2010, Shimazu Co., Kyoto, Japan). The DB-5MS column was $30 \mathrm{~m}$ in length, $0.25 \mathrm{~mm}$ id, and $0.25 \mu \mathrm{m}$ in thickness (Agilent Technologies, J\&W Scientific Products, Folsom, CA, USA). The carrier gas was helium. The GC oven temperature program was as follows: $50{ }^{\circ} \mathrm{C}$ hold for $6 \mathrm{~min}$, raised at $5{ }^{\circ} \mathrm{C} / \mathrm{min}$ to $280{ }^{\circ} \mathrm{C}$, and hold for $5 \mathrm{~min}$. The injector and detector temperatures were set at $250{ }^{\circ} \mathrm{C}$ and $280{ }^{\circ} \mathrm{C}$, respectively. The mass range was scanned from 20 to $900 \mathrm{amu}$. The control of the GC-MS system and the data peak processing were carried out by means of Shimazu's GC-MS solution software, version 2.4. Momilactones A and B were identified by comparing their retention times, molecular weight, and fragment similarities, with the standard momilactones A and B in the GC-MS. Chemical structures of momilactone $\mathrm{A}$ and $\mathrm{B}$ were confirmed as $\mathrm{C}_{20} \mathrm{H}_{26} \mathrm{O}_{3}$ and $\mathrm{C}_{20} \mathrm{H}_{26} \mathrm{O}_{4}$, respectively. Contents of momilactones $\mathrm{A}$ and $\mathrm{B}$ were quantified according to a curve established from different concentrations 1, 10, 50, and $100 \mathrm{ppm}$ of the standard momilactones A and B.

\subsection{Total phenols}

Phenolic contents prepared from upland parts of rice cultivars were measured using Folin-Ciocalteu method described by Elzaawely et al. (2005). An amount of $200 \mu \mathrm{L}$ of each sample $(0.5 \mathrm{mg} / \mathrm{L})$ was mixed with $1.0 \mathrm{~mL}$ of Folin-Ciocalteu's reagent $(10 \%)$ and $0.8 \mathrm{~mL}$ of sodium carbonate $(7.5 \%)$ was then added. 
The solutions were mixed and allowed to stand for $30 \mathrm{~min}$. The absorbance was measured at $765 \mathrm{~nm}$ using a HACH DR/4000U spectrophotometer. The total phenolic content was reported as mg gallic acid equivalents (GAE) per gram dry weight (DW).

\subsection{Total flavonoids}

The amount of total flavonoids was determined according to the method described by Djeridane et al. (2006). One $\mathrm{mL}$ of extract $(0.5 \mathrm{mg} / \mathrm{mL})$ was mixed with $1 \mathrm{~mL}$ aluminum chloride $2 \%$. The mixture was stirred and kept at room temperature for $15 \mathrm{~min}$. The absorbance was measured at $430 \mathrm{~nm}$ using a HACH DR/4000U spectrophotometer. Total flavonoids was reported as mg rutin equivalents (RE) per gram dry weight (DW).

\subsection{Antioxidant activity}

The DPPH free radical scavenging assay described by Elzaawely et al. (2005) was used to determine the antioxidant capacity of each rice cultivars. The mixture consisted of $0.5 \mathrm{~mL}$ sample extracts and $0.25 \mathrm{~mL} 0.5 \mathrm{mM} \mathrm{DPPH}$ and $0.5 \mathrm{~mL}$ of $0.1 \mathrm{M}$ acetate buffer ( $\mathrm{pH} 5.5$ ). The mixture was kept in the dark at room temperature for $30 \mathrm{~min}$. Methanol was used as a control. Radical scavenging activity was expressed as the inhibition percentage and was calculated using the formula:

$\%$ radical scavenging activity $=\left[\left(\mathrm{A}_{\text {control }}-\mathrm{A}_{\text {test }}\right) / \mathrm{A}_{\text {control }}\right]$

$$
\times 100
$$

$\mathrm{A}_{\text {control }}$ corresponds to the absorbance of the control and $\mathrm{A}_{\text {test }}$ corresponds to the absorbance of the test extract.

\subsection{Statistical analysis}

All trials of this study were repeated twice and conducted in a completely randomized block design with three replications. Data were analyzed using a two way ANOVA (analysis of variance) with significant difference determined at a confidence level of $P<0.05$. Means of drought tolerance, salinity tolerance, and weed resistance were expressed as inhibition percentage against the respective controls and calculated by the following equation:

$I_{\mu}=\frac{\mu_{C}-\mu_{T}}{\mu_{C}} \times 100$

Where $\mathrm{I}_{\mu}$ is the percentage inhibition in average over controls, $\mu_{\mathrm{C}}$ is the mean value for average specific growth rate $(\mu)$ in the controls, $\mu_{\mathrm{T}}$ is the average specific growth rate for the treatment replicates.
Rice cultivars showed maximum (five cultivars) and minimum (five cultivars) properties of each drought tolerance, salinity tolerance, and weed resistance were selected to analyze the correlation coefficients with respective contents of momilactones $\mathrm{A}$ and $\mathrm{B}$, and capacities of antioxidant, total flavonoids, and phenols.

\section{Results and discussion}

\subsection{Salinity tolerance, drought tolerance, and weed resistance}

The salinity tolerance capacity of the studied rice was presented in Table 1 and found that it was varied among rice origins and subtypes (10.6-35.5\% inhibition against controls). Of them, upland rice recorded the strongest salinity tolerance value $(35.5 \%)$, followed by upland sticky $(31.1 \%)$, and sticky rice $(30.9 \%)$, whereas hybrids were the minimum (10.6\%).

For drought tolerance, Table 1 shows that in comparison among rice origins, sticky rice was the maximum (35.2\%), followed by upland sticky (30.4\%) and upland rice (24.8\%). Foreign rice was the lowest (19.0\%), but it was not significantly different as compared with the drought tolerance values of local and foreign rice (Table 1).

In weed tolerance, the minus weed resistance values indicated promotion against controls, that the quantities of weed biomass in foreign rice were greater than that in the control plots (Table 1). There was a great variation of the weed resistance capacity among rice cultivars $(-26.5-56.3 \%)$. For rice origins, foreign rice showed the lowest weed resistance values $(-26.5 \%)$, whereas sticky rice was the maximum $(56.3 \%)$, followed by upland sticky (42.4\%) and local rice (38.8\%).

\subsection{Total flavonoids, total phenols, and antioxidant activity}

Values of total flavonoids fluctuated from $53.3-76.2 \mathrm{mg} \mathrm{g}^{-1}$ rutin (RT) equivalent among rice origins and subtypes (Table 1). Upland rice recorded the maximum value of total flavonoid, whereas the lowest value was upland sticky rice. In total phenols, among rice origins, hybrid rice was the highest $\left(17.2 \mathrm{mg} \mathrm{g}^{-1}\right.$ GAE), whereas upland sticky rice was the minimum (4.8 $\mathrm{mg} \mathrm{g}^{-1} \mathrm{GAE}$ ) (Table 1). In general, total phenols fluctuated in smaller magnitude as compared to total flavonoids and antioxidant activities. There was also a strong variation of DPPH scavenging activity among studied rice (Table 1 ). Among rice origins, hybrid rice was the maximum $\left(46.7 \mathrm{mg} \mathrm{ml}^{-1}\right)$, whereas local rice was the minimum $\left(6.9 \mathrm{mg} \mathrm{ml}^{-1}\right)$ (Table 1).

\subsection{Contents of momilactones A and B}

Amounts of momilactones A and B were strongly varied among rice cultivars (69.9-99.3 and 64.4-114.1 $\mu \mathrm{g} \mathrm{g}^{-1}$ dried 
Table 1 Comparison of agronomic and chemical properties among rice origins and subtypes

\begin{tabular}{|c|c|c|c|c|c|c|c|c|}
\hline $\begin{array}{l}\text { Origins and } \\
\text { subtypes }\end{array}$ & $\begin{array}{l}\text { Salinity } \\
\text { tolerance } \\
\text { (\% inhibition } \\
\text { against control) }\end{array}$ & $\begin{array}{l}\text { Drought } \\
\text { tolerance } \\
\text { (\% inhibition } \\
\text { against control) }\end{array}$ & $\begin{array}{l}\text { Weed resistance } \\
\text { (\% inhibition } \\
\text { against control) }\end{array}$ & $\begin{array}{l}\text { Total } \\
\text { flavonoids } \\
(\mathrm{mg} / \mathrm{g} \mathrm{RE})\end{array}$ & $\begin{array}{l}\text { Total } \\
\text { phenols } \\
(\mathrm{mg} / \mathrm{g} \text { GAE) }\end{array}$ & $\begin{array}{l}\text { Antioxidant } \\
\text { (DPPH } \\
\text { scavenging } \\
\text { activity) }(\mathrm{mg} / \mathrm{ml})\end{array}$ & $\begin{array}{l}\text { MA content } \\
(\mu \mathrm{g} / \mathrm{g})\end{array}$ & $\begin{array}{l}\text { MB content } \\
(\mu \mathrm{g} / \mathrm{g})\end{array}$ \\
\hline Hybrid & $10.6 \pm 1.8 \mathrm{c}$ & $23.1 \pm 4.2 b c$ & $9.8 \pm 28.9 \mathrm{~cd}$ & $66.9 \pm 3.3 b$ & $17.2 \pm 2.1 \mathrm{a}$ & $46.7 \pm 4.1 \mathrm{a}$ & $98.2 \pm 30.2 \mathrm{a}$ & $88.2 \pm 84.9$ \\
\hline Foreign & $12.5 \pm 1.2 \mathrm{c}$ & $19.0 \pm 3.7 \mathrm{c}$ & $-26.5 \pm 24.2 \mathrm{e}$ & $59.5 \pm 4.3 \mathrm{~cd}$ & $13.9 \pm 1.2 b$ & $27.6 \pm 4.6 \mathrm{bc}$ & $69.9 \pm 15.7 b$ & $84.6 \pm 9.6 a b$ \\
\hline Sticky & $30.9 \pm 1.3 \mathrm{a}$ & $35.2 \pm 4.6 \mathrm{a}$ & $56.3 \pm 16.4 \mathrm{a}$ & $59.1 \pm 3.7 \mathrm{c}$ & $8.8 \pm 1.5 \mathrm{c}$ & $25.1 \pm 3.9 \mathrm{bc}$ & $81.1 \pm 5.3 \mathrm{ab}$ & $90.7 \pm 21.3 \mathrm{ab}$ \\
\hline Local & $20.6 \pm 6.1 b$ & $21.7 \pm 4.8 \mathrm{bc}$ & $38.8 \pm 26.7 \mathrm{abc}$ & $74.3 \pm 2.7 \mathrm{a}$ & $8.8 \pm 1.4 \mathrm{c}$ & $6.9 \pm 4.5 \mathrm{~d}$ & $86.3 \pm 9.4 a b$ & $94.8 \pm 4.6 \mathrm{ab}$ \\
\hline Upland sticky & $31.1 \pm 1.5 \mathrm{a}$ & $30.4 \pm 2.8 \mathrm{a}$ & $42.4 \pm 25.7 \mathrm{ab}$ & $53.3 \pm 3.9 \mathrm{~d}$ & $4.8 \pm 3.3 \mathrm{~d}$ & $19.5 \pm 4.2 \mathrm{c}$ & $76.2 \pm 18.8 \mathrm{ab}$ & $64.4 \pm 22.1 \mathrm{~b}$ \\
\hline Upland & $35.5 \pm 10.3 \mathrm{a}$ & $24.8 \pm 7.4 \mathrm{bc}$ & $14.1 \pm 18.1 \mathrm{~cd}$ & $76.2 \pm 5.2 \mathrm{a}$ & $14.8 \pm 3.1 \mathrm{ab}$ & $20.9 \pm 1.2 c$ & $99.3 \pm 6.1 \mathrm{a}$ & $114.1 \pm 9.5 \mathrm{a}$ \\
\hline Indica & $14.6 \pm 2.3 b c$ & $21.3 \pm 2.3 b$ & $7.4 \pm 2.5 \mathrm{~d}$ & $66.9 \pm 2.5 b$ & $13.3 \pm 1.3 b$ & $27.1 \pm 5.0 \mathrm{~b}$ & $81.8 \pm 10.3 \mathrm{ab}$ & $108.1 \pm 24.7 \mathrm{a}$ \\
\hline Japonica & $32.5 \pm 3.3 \mathrm{a}$ & $30.1 \pm 3.0 \mathrm{ab}$ & $37.6 \pm 11.9 b$ & $63.0 \pm 3.5 \mathrm{c}$ & $9.5 \pm 1.8 \mathrm{c}$ & $21.8 \pm 1.9 \mathrm{c}$ & $85.5 \pm 6.9 \mathrm{ab}$ & $89.7 \pm 11.3 \mathrm{ab}$ \\
\hline
\end{tabular}

Values are means $\pm \mathrm{SE}$ (standard errors) Means with same letters are not significantly different $(P<0.05)$

$M A$ Momilactone A, $M B$ Momilactone B, GAE Gallic acid equivalent, $R E$ Rutin equivalent

Value with (-) indicates promotion over controls

weight, respectively) (Table 1). Contents of momilactone B were in a greater amount than momilactone $\mathrm{A}$ in all rice origins and subtypes. Upland rice showed maximum amounts of both momilactones $\mathrm{A}$ and $\mathrm{B}$, as compared to other rice origins. Momilactone A in Japonica was greater in quantity than Indica, but in contrast, a greater quantity of momilactone B was observed in Indica than Japonica. However, statistically, the quantities of momilactones A and B in the two subtypes were not significantly different (Table 1).

In previous research, the quantification of momilactones $\mathrm{A}$ and B was reported using HPLC (Lee et al. 1999; Shimura et al. 2007; Lee et al. 2002; Kong et al. 2004; Kim et al. 2007; Kato-Noguchi and Ota 2013). However, their contents can also be determined by GC-MS, which have been noted in in several reports (Matsuyama 1983; Fukuta et al. 2007; Kodama et al. 1988), as well as in this study, using standard momilactones A and B to compare their retention times, mass spectra, and fragments.

Table 2 Correlation coefficients among abiotic stress tolerance and chemical components in rice

\subsection{Comparison between two subtypes Indica and Japonica}

Results in Table 1 showed that Japonica rice obtain greater capacities of salinity tolerance, drought tolerance, and weed resistance than Indica, however total flavonoids and phenols, and antioxidant activity of Indica subtype were in great quantities and stronger than Japonica. Momilactone B in both Japonica and Indica rice were greater in quantity than momilactone A, although the amount of momilactone B was not significantly different than momilactone B in Japonica rice (Table 1).

\subsection{Correlation coefficients}

Table 2 presented the correlation coefficients of momilactones $\mathrm{A}$ and $\mathrm{B}$ among values of drought tolerance, salinity tolerance,

\begin{tabular}{|c|c|c|}
\hline Abiotic stresses & Correlation coefficients ( $\mathrm{r}$ values) & \\
\hline \multirow[t]{4}{*}{ Salinity tolerance } & $\mathrm{ST} \times \mathrm{MA}: 0.16$ & $\mathrm{ST} \times \mathrm{MB}: 0.27$ \\
\hline & $\mathrm{ST} \times \mathrm{DT}: 0.26$ & $\mathrm{ST} \times \mathrm{WR}: 0.48$ \\
\hline & ST $\times$ antioxidant activity : 0.0004 & ST $\times$ total flavonoids: 0.36 \\
\hline & ST $\times$ total phenols : 0.29 & $\mathrm{MA} \times \mathrm{MB}: 0.11$ \\
\hline \multirow[t]{4}{*}{ Drought tolerance } & $\mathrm{DT} \times \mathrm{MA}: 0.65$ & $\mathrm{DT} \times \mathrm{MB}: 0.11$ \\
\hline & $\mathrm{DT} \times \mathrm{WR}: 0.003$ & $\mathrm{DT} \times \mathrm{ST}: 0.01$ \\
\hline & DT $\times$ antioxidant activity : 0.08 & DT $\times$ total flavonoids : 0.25 \\
\hline & DT $\times$ total phenols : 0.04 & $\mathrm{MA} \times \mathrm{MB}: 0.53$ \\
\hline \multirow[t]{4}{*}{ Weed resistance } & $\mathrm{WR} \times \mathrm{MA}: 0.09$ & $\mathrm{WR} \times \mathrm{MB}: 0.001$ \\
\hline & $\mathrm{WR} \times \mathrm{ST}: 0.19$ & $\mathrm{WR} \times \mathrm{DT}: 0.26$ \\
\hline & WR $\times$ antioxidant activity : 0.04 & WR $\times$ total flavonoids : 0.18 \\
\hline & WR $\times$ total phenols : 0.003 & $\mathrm{MA} \times \mathrm{MB}: 0.53$ \\
\hline
\end{tabular}

MA Momilactone A, MB Momilactone B, ST Salinity tolerance, DT Drought tolerance, WR Weed resistance 
weed resistance, total phenols, total flavonoids, and antioxidantactivities.

It was found that values of weed resistance that corresponded to contents of momilactones A and B were extremely low $(r=0.09$ and 0.001 , respectively). However, both drought and salinity tolerance revealed much stronger correlation coefficients $(r=0.16$ and 0.27 and 0.65 and 0.11 for momilactones A and B, respectively) (Table 2) than those of weed resistance values. It also found that the antioxidant activity did not correlate to any capacity of drought and salinity tolerance and weed resistance in rice. Total phenols responded to salinity tolerance in a much stronger level $(r=0.29)$, than drought tolerance and weed resistance $(r=0.04$ and 0.003 , respectively) (Table 2). Momilactones A and B correlated in a similar level $(r=0.53)$ in drought tolerance and weed resistance, but their correlation coefficient was much lower against salinity tolerance $(r=0.11)$. Total flavonoids correlated in much stronger magnitudes against salinity tolerance, drought tolerance, and weed resistance $(r=0.36,0.25$ and 0.18 , respectively).

A number of secondary metabolites from rice plant extracts, root exudates and decomposing rice residues, have been reported as potent allelochemicals, including phenolic acids, phenyl-alkanoic acids, hydroxamic acids, fatty acids, terpenes, and indoles (Kato-Noguchi and Peters 2013). Momilactones A and B have been demonstrated as plant growth inhibitors, but the inhibitory of momilactone B was stronger than momilactone A (Kato-Noguchi et al. 2008a; Kato et al. 1977; Fukuta et al. 2007; Toyomasu et al. 2008). In quantity, the endogenous concentrations of momilactone A was greater than momilactone B (Lee et al. 1999; Chung et al. 2006; Kato-Noguchi et al. 2008a), but the secretion rates of momilactone A>momilactone B (Kato-Noguchi et al. 2008a). However, most of these experiments were conducted on several rice cultivars with similar origins. Therefore, the actual response of momilactones $\mathrm{A}$ and $\mathrm{B}$ on weed tolerance is differed among rice with different origins and sub-types, as found in this study.

Since momilactones A and B were first discovered by Kato et al. (1973), major research has been conducted on the two compounds concentrated on plant growth and pathogen (Fukuta et al. 2007; Okada et al. 2007; Hasegawa et al. 2010), and antioxidant capacity (Fukuta et al. 2007), cytotoxic and antitumor activity (Kim et al. 2007), whereas other biological activities of momilactones $\mathrm{A}$ and $\mathrm{B}$ have remained unknown. This study is the first to demonstrate that momilactones A and B correlated to the tolerance of drought and salinity in much stronger levels than the weed tolerance in rice. Molecular breeding may be much more useful than traditional breeding (Kong et al. 2011), but the location of QTLs/genes involved in plant growth inhibitors has met limited success (Jensen et al. 2001). Many QTLs involved in the drought and salinity have been detected, but these traits often do not comply with rice quality such as amylose and protein content, that is the major constraint in breeding rice tolerance to drought and salinity.

Treatments of several plant regulators such as 2,4-D IAA, and NAA, methyl jasmonate and jasmonic acid, polyamines, and brassino steroids are known to increase secondary metabolites in plants and therefore the tolerance against abiotic stresses including drought and salinity was strengthened (Ramakrishna and Ravishankar 2011). In addition, the application of exogenous abscisic acid induced drought tolerance and salinity tolerance (Lee and Luan 2012). Allantoin in grains was reported to provide rice resistant to low temperature or drought at early growth stage (Wang et al. 2012). The accumulation of osmoprotectants like proline, sugars, polyamines, and antioxidants in rice helps to reduce the drought stress (Pandey and Shukla 2015). The treatment of exogenous proline and glycinebetaine has been known to increase the salinity tolerance in rice (Sobahan et al. 2012). Contents of proline and anthocyanin were increased in salinity sensitive rice cultivar in salinity stress (Chutipaijit et al. 2011). However, this research is the first to report the involvement of momilactones $\mathrm{A}$ and $\mathrm{B}$ to the tolerance characteristics against drought and salinity in rice.

It has been observed that the momilactone biosynthetic genes are a dehydrogenase gene (AK103462) and two P-450 genes (CYP99A2 and CYP99A3) form a chitin oligosaccharide elicitor and UV-inducible gene cluster, together with OsKS4 and OsCyc1, the diterpene cyclase genes, on chromosome 4 (Shimura et al. 2007). The activation of these genes may vary among rice cultivars, origins, and subtypes Indica and Japonica that may attribute to different amounts of momilactones A and B in the studied rice cultivars. In this study, total flavonoids, total phenols, and antioxidant activity did not show correlations with drought and salinity tolerance and weed resistance in rice. Several phytochemicals were found to respond to the abiotic stresses in rice such as proline, allantoin, and abscisic acid, but they do not belong to these chemical groups. The increase of antioxidant activity in the abiotic stresses was found in several individual cultivars such as in salinity sensitive cultivars (Chutipaijit et al. 2011), but it was not examined in many rice cultivars with different origins and subtypes as in this study.

\section{Conclusion}

Although momilactones A and B were found to correlate to the drought and salinity tolerance capacities in much stronger levels than the weed resistance in rice, it needs to be verified how much momilactones $\mathrm{A}$ and $\mathrm{B}$ contribute to the tolerance of rice against drought and salinity stresses. Since momilactones A and B can be easily isolated from rice husks, the treatment of momilactones $\mathrm{A}$ and $\mathrm{B}$ to clarify the changes in drought and salinity tolerance in rice is required. In addition, momilactones $\mathrm{A}$ and $\mathrm{B}$ and their 
derivatives can be synthesized following methods described in Germain and Deslongchamps (2002) using a highly diastereoselective transanular Diels-Alder reaction on a transtrans-cis macrocylic triene. Therefore, the examination of different functional groups in chemical structures of momilactones $\mathrm{A}$ and $\mathrm{B}$ against drought tolerance and salinity tolerance capacities is also needed. Previous research investigating the role of momilactones A and B on weed tolerance was generally conducted in several rice cultivars with similar origins, therefore the actual response of momilactones A and B to these abiotic stresses on rice was not fully understood. Results of this research are helpful to the development of bioactive reagents for reducing drought and salinity stresses in rice production. It concluded that momilactones A and B play a more critical role in drought and salinity tolerance in rice than weed tolerance, as described in literature. The use of molecular markers relevant to these genes in rice breeding may also be promising to increase the drought and salinity tolerance properties in targeted commercial rice, but it needs elaboration.

Acknowledgements The authors thank the Grand-in-Aid (No. 10433096) for Scientific Research. Do Tan Khang and Phung Thi Tuyen are appreciated to their assistance to the manuscript preparation.

\section{References}

Cartwright D, Langcake P, Pryce RJ, Leworthy DP, Ride JP (1977) Chemical activation of host defence mechanisms as basis for crop protection. Nature 267:511-513. doi:10.1038/267511a0

Cartwright DW, Langcake P, Pryce RJ, Leworthy DP, Ride JP (1981) Isolation and characterization of two phytoalexins from rice as momilactones A and B. Phytochemistry 20:535-537. doi:10.1016/S0031-9422(00)84189-8

Chung IM, Hahn SJ, Ahmad A (2006) Evaluation of allelopathic potential and quantification of momilactone A, B from rice hull extracts and assessment of inhibitory bioactivity on paddy field weeds. J Agric Food Chem 54:2527-2536. doi:10.1021/jf052796x

Chutipaijit S, Cha-um S, Sompornpailin K (2011) High contents of proline and anthocyanin increase protective response to salinity in Oryza sativa L. spp. indica Sutee. Aust J Crop Sci 5:1191-1198

Djeridane A, Yousfi M, Nadjemi B, Boutassouna D, Stocker P, Vidal N (2006) Antioxidant activity of some Algerian medicinal plants extracts containing phenolic compounds. Food Chem 97:654-660. doi:10.1016/j.foodchem.2005.04.028

Elzaawely AA, Xuan TD, Tawata S (2005) Antioxidant and antibacterial activities of Rumex japonicus HOUTT aerial parts. Biol Pharm Bull 28:2225-2230. doi:10.1248/bpb.28.2225

Fukuta M, Xuan TD, Deba F, Tawata S, Khanh TD, Chung IM (2007) Comparative efficacies in vitro of antibacterial, fungicidal, antioxidant, and herbicidal activities of momilactones A and B. J Plant Interact 2:245-251. doi:10.1080/17429140701713811

Germain J, Deslongchamps P (2002) Total synthesis of $( \pm$ ) momilactone A. J Org Chem 67:5269-5278. doi:10.1021/jo0258731

Gregorio GB, Senadhira D, Mendoza RD (1997) Screening rice for salinity tolerance IRRI Discussion Paper Series no, 22, p1-30. International Rice Research Institute, Manila

Hasegawa M, Mitsuhara I, Seo S, Imai T, Koga J, Okada K, Yamane H, Ohashi Y (2010) Phytoalexin accumulation in the interaction between rice and the blast fungus. Mol Plant-Micro Intract 23: 1000-1011. doi:10.1094/MPMI-23-8-1000

Jensen LB, Courtois B, Shen L, Li ZK, Olofsdotter M, Mauleon RP (2001) Locating genes controlling allelopathic effects against barnyardgrass in upland rice. Agron J 93:16-21. doi:10.2134/agronj2001.93121x

Kato T, Kabuto C, Sasaki N, Tsunagawa M, Aizawa H, Fujita K, Kato Y, Kitahara M (1973) Momilactones, growth inhibitors from rice, Oryza sativa L. Tetrahedron Lett 39:3861-3864. doi:10.1016/0031-9422(77)83010-0

Kato T, Tsunakawa M, Sasaki N, Aizawa H, Fujita K, Kitahara Y, Takahashi N (1977) Growth and germination inhibitors in rice husk. Phytochemistry 16:45-48. doi:10.1016/0031-9422(77)83010-0

Kato-Noguchi H, Ino T (2005) Possible involvement of momilactone B in rice allelopathy. J Plant Physiol 162:718-721. doi:10.1016/j. jplph.2004.11.009

Kato-Noguchi H, Ota K (2013) Biological activities of rice allelochemicals momilactone A and B. Rice Res 1:2. doi:10.4172/jrr.1000108

Kato-Noguchi H, Peters RJ (2013) The role of momilactones in rice allelopathy. J Chem Ecol 39:175-185. doi:10.1007/s10886-0130236-9

Kato-Noguchi H, Ota K, Ino T (2008a) Release of momilactone A and B from rice plants into the rhizosphere and its bio-activities. Allelopathy J 22:321-328

Kato-Noguchi H, Ino T, Ota K (2008b) Secretion of momilactone A from rice roots to the rhizosphere. J Plant Physiol 165:691-696. doi:10.1016/j.jplph.2007.07.018

Kim SJ, Park HR, Park E, Lee SC (2007) Cytotoxic and antitumor activity of momilactone B from rice hulls. J Agric Food Chem 55:17021706. doi:10.1021/jf062020b

Kodama O, Suzuki T, Miyakawa J, Akatsuka T (1988) Ultravioletinduced accumulation of phytoalexins in rice leaves. Agric Biol Chem 52:2469-2473. doi:10.1080/00021369.1988.10869067

Kong CH, Liang WJ, Xu XH, Hu F (2004) Release and activity of allelochemicals from allelopathic rice seedling. J Agric Food Chem 52:2861-2865. doi:10.1021/jf035467i

Kong CH, Li HB, Hu F, Xu XH, Wang P (2006) Allelochemicals released by rice roots and residues in soil. Plant Soil 288:4756. doi:10.1007/s11104-006-9033-3

Kong CH, Chen XH, Hu F, Zhang SZ (2011) Breeding of commercially acceptable allelopathic rice cultivars in China. Pest Manag Sci 67: 1100-1106. doi:10.1002/ps.2154

Lee SC, Luan S (2012) ABA signal transduction at the crossroad of biotic and abiotic stress responses. Plant Cell Environ 35:53-60. doi:10.1111/j.1365-3040.2011.02426.x

Lee CW, Yoneyama K, Takeuchi Y, Konnai M, Tamogami S, Kodama O (1999) Momilactones A and B in rice straw harvested at different growth stages. Biosci Biotechnol Biochem 63:1318-1320. doi:10.1271/bbb.63.1318

Lee CW, Yoneyama K, Takeuchi Y, Ryu SN (2002) Quantification of momilactones A and B in rice straw. Korean J Crop Sci 47:283-285

Matsuyama N (1983) On the detection of momilactones A and B in healthy and blast-infected rice leaves by GLC. Japan J Phytopathol 49:200-205. doi:10.3186/jiphytopath.49.200

Nachimuth VV, Muthurajan R, Duraialaguraja S, Sivakami R, Pandian BA, Ponniah G, Gunasekaran K, Swaminathan M, Suji KK, Sabariappan R (2015) Analysis of population structure and genetic diversity in rice germplasm using SSR markers: an initiative towards association mapping of agronomic traits in Oryza sativa. Rice 8:30. doi: $10.1186 / \mathrm{s} 12284-015-0062-5$

Okada A, Shimizu T, Okada K, Kuzuyama T, Koga J, Shibuya N, Nojiri H, Yamane H (2007) Ecilitor induced activation of the methylerythritol phosphate pathway toward phytoalexins biosynthesis in rice. Plant Mol Biol 65:177-187. doi:10.1007/s11103-007-9207-2

Pandey V, Shukla A (2015) Acclimation and tolerance strategies of rice under drought stress. Rice Sci 22:147-161. doi:10.1016/j.rsci.2015.04.001 
Pandey S, Bhandari H, Hardy B (2007) Economic costs of drought and rice farmers' coping mechanisms: a cross-country comparative analysis. International Rice Research Institute, Los Baños, p 203

Ramakrishna A, Ravishankar GA (2011) Influence of abiotic stress signals on secondary metabolites in plants. Plant Signal Behav 6:1720 1731. doi:10.4161/psb.6.11.17613

Shimura K, Okada A, Okada K, Jikumaru Y, Ko KW, Toyomasu T, Sassa T, Hasegawa M, Kodama O, Shibuya N, Koga J, Noriji H, Yamane $\mathrm{H}$ (2007) Identification of a biosynthetic gene cluster in rice for momilactones. J Biol Chem 282:34013-34018. doi:10.1074/jbc. M703344200

Sobahan MA, Akter N, Ohno M, Okuma E, Hirai Y, Mori IC, Nakamura Y, Murata Y (2012) Effects of exogenous proline and glycinebetaine on the salt tolerance of rice cultivars. Biosci Biotechnol Biochem 76: 1568-1570. doi:10.1271/bbb.120233

Toyomasu T, Kagahara T, Odaka K, Koga J, Hasegawa M, Mitsuhashi W, Sassa T, Yamane H (2008) Diterpene phytoalexins are biosynthesized in and exudated from roots of rice seedlings. Biosci Biotechnol Biochem 72:563-567. doi:10.1271/bbb.70677

Wang P, Kong CH, Sun B, Xu XH (2012) Distribution and function of allantoin (5-ureidohydantoin) in rice grains. J Agric Food Chem 60: 2793-2798. doi:10.1021/jf2051043

Yoshida S, Forno DA, Cook JH, Gomez AK (1976) Laboratory manual for physiological studies of rice. International Rice Research Institute (IRRI), Los Baños, pp 61-66 